
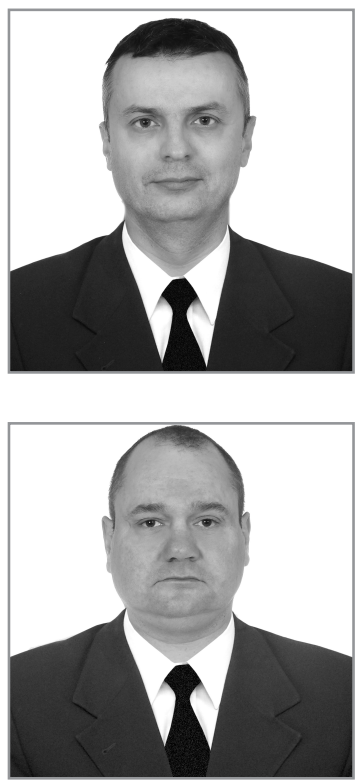

Vitali Serafimov*

Lawyer, $\mathrm{PhD}$ in Law, Associate Professor,

Managing Partner of the Legal Group

"Vitali Serafimov and Partners",

Managing Partner "Chinese Legal Center in Odessa",

Member of the Council of Odessa Regional Organization of the Union of Lawyers of Ukraine

(Dobroslav, Ukraine)

ORCID: https://orcid.org/ 0000-0002-0436-2071

\section{Vladyslav Rudenko**}

Lawyer, $\mathrm{PhD}$ in Law,

Partner of the Legal Group

"Vitali Serafimov and partners"

(Dobroslav, Ukraine)

ORCID: https://orcid.org/0000-0002-4229-249X

*Vitali Serafimov, Lawyer, PhD in Law, Associate Professor, Managing Partner of the Legal Group "Vitali Serafimov and Partners", Managing Partner "Chinese Legal Center in Odessa", Member of the Council of Odessa Regional Organization of the Union of Lawyers of Ukraine (Centralna St., 48A, Dobroslav, Lymanskiy district, Odessa region, Ukraine).

**Vladyslav Rudenko, Lawyer, PhD in Law, Partner of the Legal Group "Vitali Serafimov and partners" (Centralna St., 48A, Dobroslav, Lymanskiy district, Odessa region, Ukraine).

UDC 347.791.6:343.1

DOI 10.26886/2524-101X.6.2018.2

\title{
UNLAWFUL ARREST OF A SHIP UNDER FOREIGN FLAG IN UKRAINE
} (Article is dedicated to Professor Dodin E.V.)

\section{НЕЗАКОННИЙ АРЕШТ СУДНА ПІД ІНОЗЕМНИМ ПРАПОРОМ В УКРАЇНІ (Статтю присвячено професору Додіну С.В.)}

\section{ABSTRACT}

The article is focused on problems of arrest and detention of foreign ships in the ports of Ukraine. The arrest of a ship is not the same as the arrest of usual 
property, therefore, the authors note that the maritime legislation of Ukraine should be supplemented by an independent act containing procedural rules by which the procedure for examining cases of arrest of foreign ships by the judicial authorities of Ukraine would be determined for the so-called. "Marine claims". Nowadays the world is practicing arrest of the ship for its direct debts "in rem". However in our country the arrest can only be made if it's legal or individual property. And risk of the lawyers who represent the claimant's interest in relation to maritime claims is very high because the company indicated in the statement of claim and the petition for the arrest as the owner of the vessel may actually be either an operator or mortgagee or any other offshore company headed by one and the same person. The authors submit, that Ukrainian legislation has such gaps and imperfections about the mechanism of arrest, first of all, foreign sea vessels, that some law enforcement agencies have the opportunity to return to practice more than twenty years ago when prosecutors and tax police officers tried to arrest property in criminal proceedings in order to provide material evidence. In order to represent such gaps, the authors give and analyze the Kyiv Appeal Court's decision. It was noted that due to this decision finally the final point was put in the collision of the legislation of Ukraine, the counteraction to the illegal arrest of a foreign vessel in criminal prosecution was made, a legitimate decision was made and our state prevented numerous negative consequences and losses abroad. At the same time, unfortunately, there is completely probable possibility that Ukraine may be required to pay all material losses during the month of finding a foreign ship under unlawful arrest with crew and cargo or by a decision of the Ukrainian or the European Court.

The key words: vessel, arrest, arrest ship, unlawful arrest of the vessel, marine claims, criminal proceedings, Ukraine.

Acceptance of the Merchant Shipping Code organized the creation of a new branch of law in Ukraine called Maritime Law of Ukraine. At that time the Code played mainest role in regulating legal relations arising from merchant shipping, but beyond its borders there were many outstanding legal issues. To a certain extent those issues were solved in connection with ratification by the Verkhovna Rada of Ukraine of a number of International Conventions and Agreements, including the UN Convention on the Law of the Sea 1982 and the International Convention Relating to the Arrest of Sea-Going Ships 1952. However, there are still problems that require legal permission. First of all, should identify the problem of arrest and detention of ships and especially foreign ships in Ukrainian ports .

The arrest of a ship under it's direct debts "in rem" is practiced all over the world. However in our country the arrest can only be made if it's legal or individual property. And the risk of the lawyers who represent the claimant's interest in relation to maritime requirements is very high because the company indicated in the statement of claim and the petition 
for the arrest as the owner of the vessel may actually be either an operator or mortgagee or any other offshore company headed by one and the same person.

The only obstacle is hte absence of rules regulating the mechanism of arrest and detention of foreign ships in the ports of Ukraine. Although the chapter 4 of the MSC of Ukraine lists the grounds for the arrest, however, general and economic courts and Maritime Arbitration Comission can not exercise their points. This is due to the fact that the bases for arrest and detention of vessels provide for the norms of the Maritime Law, and the procedure for review is regulated by the norms of other branches of law of the Civil Procedure Code of Ukraine and the Criminal Procedure Code of Ukraine. These acts do not take into account the specifics of a situation such as the arrest of ships.

The arrest of a ship is not the same as the seizure of ordinary property, therefore, in our opinion, the maritime legislation of Ukraine should have an independent act containing procedural rules by which the procedure for considering of cases of arrest of foreign ships by the judicial authorities of Ukraine on the basis of so-called "maritime claims". Taking into account the requirements of judicial practice, once the State Research and Development Institute of the Merchant Marine of Ukraine (UkrNIIMF) developed a draft Law of Ukraine "About the arrest of ships", which envisaged, first of all, amendments to the Commercial Procedure Code and the Civil Procedure Code of Ukraine. We would be agree that the procedural rules governing proceedings for the imposition of an arrest on a ship under a foreign flag under "maritime claims" should be established and only when the courts of Ukraine will be able to fully exercise the powers provided for in art. 41 of MSC of Ukraine. However, it is submitted that these norms should not be in the Commercial Procedure Code of Ukraine, the Civil Procedure Code of Ukraine, the Criminal Procedure Code of Ukraine but in the MSC of Ukraine, because the procedural rules of one industry should serve the realization of the substantive law of this branch.

The norms which determine the bases of arrest of ships regulate too specific relations for the realization of the owner of his right not falling under the scope of civil law. This is the Institute of Maritime Law, therefore, the execution of the arrest of ships in the ports of Ukraine should be provided by the MSC of Ukraine, especially as there are many procedural norms in it. Legislative practice is known cases of combining in one codification act norms Substantive and Procedural Law (for example 
the Code of Administrative Offences of Ukraine), therefore expanding the MSC due to the inclusion in it of the rules governing the specificity of consideration of cases of arrest of ships does not contradict the rules of legislative technique.

There is a question over the content of these norms. In our opinion, in this case it is reasonable to use the experience of the states with a huge regulatory framework regulating the arrest and detention of ships with a solid judicial practice in relation to it's application.

Also, because in our legislation there are such questions about the mechanism of arrest, first of all foreign sea-going vessels, some law-enforcement authorities have returned to practice more than twenty years ago, when prosecutors and tax police tried to arrest property for criminal proceedings, especially such "thin matter" as a ship with crew and cargo on board, in order to provide material evidence.

Therefore in our opinion, a recent example from the practice of the Legal Group "Vitaliy Serafimov and Partners" - the decision of the Kyiv Court of Appeal on this issue may cause interest of readers.

This example concerns the property of bona fide foreign shipowners but is not a property dispute and is not a "maritime requirement".

\section{KYIV APPEAL COURT}

Case No. 11 -ss/824/1068/2018

Category Art. $170 \mathrm{CPC}$

of Ukraine
Investigative judge in the

1 st instance Vyshnyak M.V.

Speaker: Masenko D.Ye.

\section{DECISION \\ IN THE NAME OF UKRAINE}

On November 13, 2018, a panel of judges of the Chamber of Criminal Cases of the Kyiv Court of Appeal composed of:

Presiding Judge Masenko D.Ye.

Judges Palenik I.G., Prysyazhnyuk O.B.

Secretary of the court session Parsamyan A.A.

With:

Prosecutor Olefir Yu.O.

Representative of the owner of the property, lawyer Rudenko V.G. 
considered at an open court hearing in Kyiv, an appeal against a representative of a foreign company Layla Shipholding Co. attorney Rudenko V.G., on the decision of the investigating judge of the Solomyansky District Court of Kyiv dated October 11, 2018,-

\section{DECREED}

This decision approved the request of the detective of the National Bureau of the Fourth Detective Division of the Main Detective Department of the National Anti-Corruption Bureau of Ukraine Belei V.D., agreed by the prosecutor of the Second Department of the Procedural Management Department, support of the state prosecution and representation in the court of the Specialized Anti-Corruption Prosecutor's Office of the General Prosecutor's Office of Ukraine Olefir Yu.O. and has been seized, in the form of a prohibition on alienation, disposal and use, on the Princess Layla vessel (IMO number 9149677, formerly known as Clipper Faith), which is owned by Layla Shipholding Co (IMO Company Number 5902298, country of registration Liberia, company address: Megalopoles Street, Kallithea, Athens, Greece).

When making a decision, the investigating judge took into account the existence of legal grounds for arrest, and concluded that there was a need to satisfy a detective's request and impose an arrest on the property specified in the petition, with the aim of ensuring the preservation of material evidence.

Disagreeing with such a decision of the court of first instance, the representative of the foreign company "Layla Shipholding Co" - the lawyer Rudenko V.G., filed an appeal, in which he requests to cancel the decision of the investigating judge, referring to its illegality and insufficiency, to arrest the merchant vessel Princess Layla.

In support of the appeal, the appellant states that the foreign company Layla Shipholding Co, which is not a resident of Ukraine, is the owner of the commercial freight vessel Princess Layla, the country of registration of the vessel Liberia, the port of registration of the vessel FREETOWN, type of vessel, general cargo ship, mentioned vessel goes under the flag of the Republic of Sierra Leone, claims that a merchant vessel is the property of a company and was acquired legally.

In addition, the lawyer indicates that in the decision of the investigator, the judge does not specify the type and class of the vessel, there is no reference to the ship's documents, in accordance with the requirements of 
Art. 35 MSC (Merchant Shipping Code) of Ukraine adds that the court of first instance did not take into account the norms of the MSC of Ukraine and international maritime law and did not specify under which flag goes the disappeared ship "Clipper Faith" and "Princess Layla".

As a result, the appellant draws the attention of the court to the fact that the merchant vssel "Princess Layla" is not a "Clipper Faith" vessel and this material object is not a mean of committing a criminal offense.

The author of the appeal claims that the master of the vessel got acquainted with the copy of the appealed decision on October 12, 2018. In connection with that fact, the appeal was filed only on October 17, 2018. Therefore, he asked to renew his term for appeals because he was absent for valid reasons, namely, the consideration of a detective's request took place in the absence of a representative of the owner of the property.

The petition of the representative of the foreign company Layla Shipholding Co - the lawyer Rudenko V.G., regarding the renewal of the time limit for appeals on the grounds set out in the appeal, the panel of judges considers it to be satisfactory, since, according to the panel of judges, this period is missed from the sufficient reasons.

Having heard the report of the judge, the explanation of the representative of the owner of the property, who supported the appeal and asked for its satisfaction, the prosecutor who objected to the satisfaction of the appeal and requested the decision of the investigator judge to remain unchanged, after examining the materials of the proceedings and checking the arguments of the appeal, the panel of judges considers that an appeal complaint is subject to satisfaction, proceeding from the following.

According to the materials submitted to the Court of Appeal, in the proceedings of the National Bureau of the Fourth Detective Division of the Main Detective Department of the National Anti-Corruption Bureau of Ukraine there are materials of criminal proceedings No. 42015000000000865, the details of which were entered into the Unified Register of Pre-trial Investigations on the grounds of the criminal offense provided for in the Unified Register of Pre-trial Investigations on April 30, 2015, Part 5 of Art. 191 of the Criminal Code of Ukraine.

Detective of the National Bureau of the Fourth Detective Division of the Main Detective Department of the National Anti-Corruption Bureau of Ukraine Belei V.D., in agreement with the prosecutor of the second department of the procedural management department, supporting the state prosecution and representation in the court of the Specialized 
Anti-Corruption Prosecutor's Office of the General Prosecutor's Office of Ukraine Olefir Yu.O., appealed to Solomyansky district court of Kyiv with the request for arrest, in the form of a prohibition on alienation, disposition and use of the Princess Layla vessel (IMO number 9149677, formerly known as Clipper Faith), which is owned by Layla Shipholding Co. (IMO Company Number 5902298, country of registration Liberia, address: Megalopoles Street, Kallithea, Athens, Greece), which was approved by the decision of the investigating judge of the Solomyansky district court of Kyiv on October 11, 2018.

At the same time, the panel of judges cannot agree with the conclusions of the investigating judge on the proof of the grounds for satisfying the request of a detective and imposing an arrest, taking into account the following circumstances.

Thus, the materials submitted to the Court of Appeal found that the National Anti-Corruption Bureau of Ukraine was investigating criminal proceedings No. 42015000000000865, according to which the officers of the PJSC SC "Sea Trident”, PJSC "Ukrainian Danube Shipping Company" acting in agreement with the officials of the Ministry of Infrastructure of Ukraine, in violation of the requirements of Part 2 of Art. 9 of the Law of Ukraine "On the Management of State Property Objects", without the permission of the Cabinet of Ministers of Ukraine, and the State Property Fund of Ukraine, sold to the foreign companies

the merchant vessels, which were property of the state, resulting in losses to the state amounting to 41 million US dollars.

In substantiating the grounds of the fact that the criminal offense has been committed, provided for in Part 5 of Art. 191 CPC of Ukraine, the detective added to the petition an extract from the Unified Register of Pre-trial Investigations, a letter from the Ministry of the Kingdom of the Netherlands, a request for international legal assistance dated May 20, 2018, a copy of the decree of the investigating judge of the Solomyansky District Court of Kyiv dated Novemebr 5, 2016, documents in foreign the language (13 p. turnover-22 turnover), the accompanying letter on the referral of criminal proceedings to the senior detective of the National AntiCorruption Bureau of Ukraine Savkin O.S., documents in a foreign language (p. 23 turnover-31), the protocol for the execution of the request the legal assistance of Ukraine, materials for the implementation of the request for international legal assistance from the Kingdom of the Netherlands with a translation, a copy of the Charter of the Joint Stock Shipping Holding 
Company "Sea Trident", a copy of the Charter of the Joint-Stock Shipping Holding Company "Sea Trident" (new edition), a copy of the Charter of Open Joint-Stock Shipping Company "Sea Trident" (new edition), a letter to OJSC Shipping Company "Sea Trident", pages from the Internetwebsite in a foreign language, the inspection report dated October 10, 2017, a copy of the cover letter to the National Anti-Corruption Bureau of Ukraine, a copy of the power of attorney with the translation, the inspection report dated October 11, 2018, extracts from the Internet web-site in a foreign language, the decision on the recognition of material assets as evidence dated October 10., 2018, a page from the Internet web-site.

The presented documents, according to the detective, contain facts and circumstances which give grounds for concluding that the ship "Princess Layla" (IMO number 9149677, formerly known as "Clipper Faith"), the ownership of which is registered by Layla Shipholding Co., is evidence of committing an offense set forth in Part 5 of Art. 191 CPC of Ukraine, however, with such a conclusion, the panel of judges cannot agree, as the materials attached to the petition do not contain the facts of the circumstances referred to by the initiator of the petition, proceeding from the following.

Thus, the documents attached to the petition do not contain facts and circumstances which would indicate the unlawful acquisition of the vessel "Princess Layla" (IMO number 9149677, the former name "Clipper Faith"), a foreign company Layla Shipholding Co.

Substantiating the request of a detective, the prosecutor referred to the circumstances that the transfer (selling) of the ship took place without the consent of its owner in the person of the state of Ukraine, along with the petition and the documents attached thereto, there is no reference to the document that would change the owner.

In the court session, the prosecutor referred to the fact that the change of ownership may have occurred by selling the vessel or by transferring ownership to ATB Bank in the repayment of debt under a loan agreement, the money for which was sent to the account. In any case, in the opinion of the pre-trial investigation body, the transfer of ownership took place without the consent of the owner in the person of the state of Ukraine.

Along with this, the arguments presented have the character of an assumption and cannot be the basis for such an interference with the rights and freedoms of the property owner who owns the property legally.

Referring to the unlawfulness of the vessel's withdrawal from its own offshore company owned by the State of Ukraine, the pre-trial investigation 
authority would have to establish the circumstances of the transfer of the ownership of the vessel to a foreign company and confirm them with documents showing the alleged illegality of such alienation.

The analysis of the above facts and circumstances should have been carried out by the investigating judge when making a decision, that there was no reason for such a decision.

In the opinion of the panel of judges, only a clear indication of the circumstances of the disputed vessel's disposal on the property of one company in favor of another provides the investigating judge with the possibility of concluding that his arrest is necessary as evidence in criminal proceedings; otherwise, such a decision will be based on the assumptions which are unacceptable.

The reference of the pre-trial investigation body to the circumstances in which the ship was withdrawn from the property of an offshore company owned by the State of Ukraine, in any case without obtaining the appropriate consent, cannot be the reason for the satisfaction of the petition because of the absence in a petition the reference to the withdrawal mechanism that deprives the college judges to conclude on the need for such a permit, in particular the transfer of ownership of the vessel to ATB Bank, in connection with non-fulfillment of the terms of the loan agreement.

The recognition of property as evidence in a criminal proceeding does not constitute grounds for arrest, and the decree itself does not justify the existence of a need for the established value of the vessel.

Thus, the investigating judge has made decisions, conclusions of which do not correspond to the actual circumstances of the case, so it is subject to cancellation with making the new decision to refuse to satisfy the request of the detective.

Guided by Art. 170, 171. 173, 309, 376, 404, 405, 407, 422 of the CPC of Ukraine, panel of judges, -

\section{DECIDED:}

To cancel the decision of the investigating judge of the Solomyansky District Court of Kyiv dated October 11, 2018, which satisfied the petition of the detective of the National Bureau of the Fourth Detective Division of the Main Detective Division of the National Anti-Corruption Bureau of Ukraine Belei V.D. and seized, in the form of a prohibition on alienation, disposal and use, on the Princess Layla vessel (IMO number 9149677, formerly known as Clipper Faith), which is owned by Layla Shipholding 
Co (IMO Company Number 5902298, country of registration Liberia, company address: Megalopoles Street, Kallithea, Athens, Greece).

To satisfy an appeal lodged by Layla Shipholding Co representative lawyer Rudenko V.G. and renew the time limit for appeals.

To make a new decision refusing to satisfy the request of the detective of the National Bureau of the Fourth Detective Division of the Main Detective Department of the National Anti-Corruption Bureau of Ukraine Belei V.D. on the imposition of an arrest, in the form of a prohibition on alienation, disposal and use, on the ship "Princess Layla" (IMO number 9149677 formerly known as "Clipper Faith"), which is owned by Layla Shipholding Co (IMO Company Number 5902298, country of registration Liberia, address of the company: Megalopoles Street, Kallithea, Athens, Greece).

The decision of the Court of Appeal is not subject to appeal.

Masenko D. Ye. /signed/

\section{JUDGES:}

Palenyk I.G. /signed/

Prysyazhnyuk O.B. /signed/

Of course we would like to give our comments, such as:

A foreign ship-owner appealed to the Legal Group "Vitali Serafimov and Partners" with request about rendering of legal assistance to him for the release of his arrest due to the private property of the vessel "Princess Layla" which was arrested according to the decision of the investigating judge of the Solomensky District Court of Kyiv, from October 11, 2018 in the form of a ban on alienation, disposition and use in the port of Olvia (Nikolaev).

After reviewing the documents provided, namely, with the decision of the investigator of the judge of the Solomensky District Court of Kyiv on October 11, 2018, it was discovered that the National Anti-Corruption Bureau of Ukraine was investigating criminal proceedings against officials of an offshore company owned by Ukraine and officers of the Ministry of Infrastructure of Ukraine (part 5 art.191 of the Criminal Code of Ukraine "Assignment, misappropriation of property or taking possession of it through abuse of office" note to the author), which without the permission of the Cabinet of Ministers of Ukraine and the State Property Fund of Ukraine more than a decade ago sold foreign merchant ships owned by the state, resulting in losses 
to the state amounting to $\$ 41$ million. Among the vessels mentioned it might have been a vessel named "Princess Layla", the flag of Sierra Leone but the decree indicated the ship "Clipper Faith", the flag of Liberia.

Firstly:

- it had not been established how the ship, which more than ten times visited different seaports of Ukraine, was not arrested earlier in this case, any claims of material, corporate and any other right on the part of the state Ukraine the ship-owner had not received.

Secondly:

- it is not clear how the law-enforcement authorities were not able to verify the history of the disputed vessel and did not find that the previous name of the vessel since 2013 was "Island Mariner", the flag of Liberia, and from 2015 "Princess Layla", the flag of Sierra Leone.

In addition, in the court hearing, when considering the appeal, the prosecutor of the SAP did not submit to the court the proper evidence of alienation of the vessel. And all the evidence is based on assumptions, suggestions and etc. According to the opinion of the panel of judges of the Kyiv Court of Appeal, only a clear indication of the circumstances in which the disputed vessel was removed from the property of one company in favor of another, would enable the investigating judge to infer that it must be arrested. In the court session, the prosecutor of the SAP did not provide any evidence or mechanism for the initial change of ownership of movable property as a ship.

As established by the Legal Group "Vitali Serafimov and Partners", having legally acquired the merchant vessel in 2015 a bona fide purchasership owner received, in accordance with international law, from the Maritime Administration of the Government of the Republic of Liberia the Certificate of the right to property and encumbrances, which clearly identified that the ship does not have any credits to mortgages, lieins or other encumbrances. According to his own wish, the new ship-owner gave his property as a merchant ship a new name "Princess Layla" and re-registered the flag in the Republic of Sierra Leone. In support of the documents submitted, the Legal Group "Vitali Serafimov and Partners" received a confirmation letter from the Maritime Administration of the Republic of Sierra Leone, in which the Administration confirmed that our client - the ship-owner of the arrested property - is a fair owner of the vessel and has all the necessary legal documents, which in full compliance with the requirements of International Maritime law. 
Considering that the procedural position of the criminal case was not determined by the owner of the maritime merchant vessel NABU and applied for a review without the participation of the ship-owner and a hearing on the consideration of the petition of the investigator NABU, on the arrest of a merchant ship in accordance with the court ruling of the first instance was held in closed mode, the owner of the ship "Princess Layla" and his authorized Legal Group "Vitali Serafimov and Partners" did not have the procedural right to reading the materials of the case in full, in this connection we have had no opportunity to review the case, especially with a foreign bank credit agreement secured which vessels were sold. In this category of cases, the legislator has set the time limit for filing an appeal for 5 days.

Our British and Greek colleagues in Law Firms were very surprised at the decision of the court of Ukraine regarding the arrest of a foreign ship with crew and cargo on board and in turn, remembering the international maritime relations of the 90 's, began to prepare for the procedure of arrest of movable property abroad, which belongs to Ukraine and began appealing to state institutions and representations in international organizations of Ukraine abroad.

That is, at risk of "mirror" arrest of Ukrainian property abroad, more than a month were seagoing vessels, airplanes and cars belonging to Ukraine.

Such actions took place approximately more than twenty years ago during my professional cooperation in the State Company "Black Sea Shipping Company" with the Law Company "Lawrence Graham", such as:

- when the High Court of London was first released from the arrest of "Nazim Hikmet", a flag of Ukraine and then one typical ship-sistership "Zorinsk", a flag of Ukraine with reference to the norm of state immunity from arrests. Upon request of the Heads of the Ministry of Transport of Ukraine, according to which the Black Sea Shipping Company is a state shipping company and owner of state-owned vessels in Ukraine, it is the State Property Fund of Ukraine, therefore the ships are state-owned and are under state immunity from arrests as warships. English lawyers receiving these arguments, brought these claims to court and accordingly received a precedent. All foreign shipping lenders immediately began to arrest the Ukrainian property abroad. The vessels under the Ukrainian flag are still in the context of this precedent, which was made by the state of Ukraine and are limited in movement and may be arrested by the lenders of the Black Sea Shipping Company. 
Unfortunately, in connection with unprofessional fulfilment of some officials' obligations in state institutions and investigative bodies, the authority of our state, especially in the international arena of maritime merchant shipping, is not so strong. As then became known to the shipowner that the Ministry of Infrastructure of Ukraine has initiated the imposition of an arrest on a foreign merchant ship "Princess Layla".

In view of the above we can summarize in this case that, by the decision of the Court of Appeal judges, who were able to put a final point in the conflict of Ukrainian legislation and put the final point in this case on illegal arrest of a foreign ship and make a grounded legal decision, our state prevented possible negative consequences and losses abroad. Unfortunately, in the future the state may be required to pay all material losses during the month of finding a ship under unlawful arrest with crew and cargo or by a decision of the Ukrainian or the European Court.

\section{REFERENCES}

Convention on the Law of the Sea 1982 (UN). Official web-site of the UN. $<$ http://www.un.org/Depts/los/convention_agreements/texts/unclos/unclos_e.pdf $>$

Hospodarskyi protsesualnyi kodeks Ukrainy 1991 (Verkhovna Rada Ukrayiny). [Commercial Procedure Code of Ukraine 1991 (Verkhovna Rada of Ukraine)]. Vidomosti Verkhovnoi Rady Ukrainy. [Statements of Verkhovna Rada of Ukraine], 1992, 6, 56. [in Ukrainian].

International Convention Relating to the Arrest of Sea-Going Ships 1952 (UN). Official web-site of the UN. <https://treaties.un.org/doc/Publication/UNTS/Volume\%20439/ volume-439-I-6330-English.pdf>

Kodeks torhovelnoho moreplavstva 1995 (Verkhovna Rada Ukrayiny). [Code of Merchant Shipping of Ukraine 1995 (Verkhovna Rada of Ukraine)]. Vidomosti Verkhovnoi Rady Ukrainy. [Statements of Verkhovna Rada of Ukraine], 47-52, 349. [in Ukrainian].

Kryminalnyi kodeks Ukrainy 2001 (Verkhovna Rada Ukrayiny). [Criminal Code of Ukraine 2001 (Verkhovna Rada of Ukraine)]. Vidomosti Verkhovnoi Rady Ukrainy. [Statements of Verkhovna Rada of Ukraine], 25, 131. [in Ukrainian].

Kryminalnyi protsesualnyi kodeks Ukrainy 2012 (Verkhovna Rada Ukrayiny). [Criminal Procedure Code of Ukraine 2012 (Verkhovna Rada of Ukraine)]. Vidomosti Verkhovnoi Rady Ukrainy. [Statements of Verkhovna Rada of Ukraine], 2013, 474, 88. [in Ukrainian].

Tsyvilnyi protsesualnyi kodeks Ukrainy 2004 (Verkhovna Rada Ukrayiny). [Civil Procedure Code of Ukraine 2004 (Verkhovna Rada of Ukraine)]. Vidomosti Verkhovnoi Rady Ukrainy. [Statements of Verkhovna Rada of Ukraine], 40, 1530, 492. [in Ukrainian]. 


\begin{abstract}
АНОТАЦІЯ
Серафімов В. В., Руденко В. Г. Незаконний арешт судна під іноземним прапором в Украӥні. - Стаття.

Статтю присвячено проблемам арештів та затримання іноземних суден у портах України. Арешт судна не є тотожним арешту звичайного майна, тому автори відзначають, що морське законодавство України повинно бути доповнене самостійним актом, який містив би процесуальні норми, за допомогою яких був би визначений порядок розгляду справ про арешт іноземних суден судовими органами України за т. зв. “морськими вимогами”. Сьогодні у світі практикується арешт судна за його прямими боргами “in rem”, однак в Україні накласти арешт можна лише щодо судна як майна юридичної або фізичної особи. Ризик адвокатів, які представляють інтереси позивачів щодо морських вимог дуже великий, бо компанія, зазначена у позовній заяві та клопотанні про арешт як власник судна може у дійсності виявитися або оператором, або заставодержателем, або будь-якою іншою офшорною компанією, головою яких є одна й та ж сама особа. Автори відзначають, що в українському законодавстві наявні такі прогалини та недосконалості у визначенні механізму арешту, в першу чергу, іноземних морських суден, що деякі правоохоронні органи мають змогу повернутися до практики більше ніж двадцятирічної давнини, коли працівники прокуратури та податкової міліції намагалися арештовувати майно у кримінальних провадженнях 3 метою забезпечення речових доказів. 3 метою репрезентації таких прогалин авторами наведено та проаналізовано рішення Київського апеляційного суду. Відзначено, що завдяки цьому рішенню нарешті було поставлено остаточну крапку в колізіях у законодавстві України, здійснено протидію незаконному арешту іноземного судна у кримінальному провадженні, винесено обгрунтоване законне рішення, а нашою державою попереджено чисельних негативних наслідків та збитків за кордоном. При цьому, на жаль, залишилася цілковито вірогідна можливість того, що Україна має сплатити усі матеріальні збитки за місяць знаходження під незаконним арештом судна з екіпажем та вантажем за рішенням або українського, або європейського суду.
\end{abstract}

Ключові слова: судно, арешт, арешт судна, незаконний арешт судна, морська вимога, кримінальне провадження, Україна.

\footnotetext{
АННОТАЦИЯ

Серафимов В. В., Руденко В. Г. Незаконный арест судна под иностранным флагом в Украине. - Статья.

Статья посвящена проблемам арестов и задержаний иностранных судов в портах Украины. Арест судна не тождественнен аресту обычного имущества, в связи с чем авторы отмечают, что морское законодательство Украины должно быть дополнено отдельным актом, содержащим процессуальные нормы в которых был бы определен порядок рассмотрения дел об аресте иностранных судов судебными органами Украины по т. н. “морским требованиям”. Сегодня в мире практикуется арест судна по его прямыми долгами “in rem”, однако в Украине
} 
наложить арест можно только на суда как имущество юридического или физического лица. Риск адвокатов, представляющих интересы истцов в отношении морских требований очень велик, поскольку компания, указанная в исковом заявлении и ходатайстве об аресте как владелец судна может в действительности оказаться или оператором, или залогодержателем, или любой другой оффшорной компанией, главой которых является одно и то же лицо. Авторы отмечают, что в украинском законодательстве имеются такие пробелы и несовершенства в определении механизма ареста, в первую очередь, иностранных морских судов, что некоторые правоохранительные органы могут вернуться к практике более чем двадцатилетней давности, когда работники прокуратуры и налоговой милиции пытались арестовывать имущество в уголовных производствах с целью обеспечения вещественных доказательств. С целью репрезентации таких пробелов авторами приведено и проанализировано решение Киевского апелляционного суда. Отмечено, что благодаря этому решению наконец была поставлена точка в коллизиях в законодательстве Украины, осуществлено противодействие незаконному аресту иностранного судна в уголовном производстве, вынесено обоснованное законное решение, а нашим государством предупреждены многочисленные негативные последствия и убытки за рубежом. При этом, к сожалению, вероятна возможность того, что Украина должна будет выплатить все материальные убытки за месяц нахождения под незаконным арестом судна с экипажем и грузом по решению или украинского, или европейского суда.

Ключевые слова: судно, арест, арест судна, незаконный арест судна, морское требование, уголовное производство, Украина. 